\title{
Sense of Femininity in Ho Xuan Huong's Poetry
}

\author{
Van Hoa Pham \\ Faculty of Literature \& History, Da Lat University, Da Lat, Vietnam \\ Email: hoapv@dlu.edu.vn
}

How to cite this paper: Pham, V.H. (2022) Sense of Femininity in Ho Xuan Huong's Poetry. Open Access Library Journal, 9: e8291.

https://doi.org/10.4236/oalib.1108291

Received: December 11, 2021

Accepted: January 24, 2022

Published: January 27, 2022

Copyright (C) 2022 by author(s) and Open Access Library Inc.

This work is licensed under the Creative Commons Attribution International License (CC BY 4.0).

http://creativecommons.org/licenses/by/4.0/

(c) (i) Open Access

\begin{abstract}
"The queen of Nom poetry" in the late Le and early Nguyen Dynasty period, Ho Xuan Huong is the leading female poet of Vietnamese medieval literature. Her poetry presented a sense of femininity, protested against Feudal Confucianism, and affirmed the personality and position of women in the society. Based on feminist theory, we would like to affirm the sense of femininity in Ho Xuan Huong's poetry in the pursuit of a desire for self-chosen love, an equal and self-controlled marriage system, and autonomy in communication and composition. The article contributes to solving problems related to perception of gender theory and the case of Ho Xuan Huong's poetry. With what she has experienced in life, Ho Xuan Huong's poetry expressed the sense of desire to hold her head up high in the very special male-dominated world. We believe that the sense of femininity in Ho Xuan Huong's poetry has to a certain extent overturned the gender inequality of men and women in the Confucian society.
\end{abstract}

\section{Subject Areas}

Culture

\section{Keywords}

Vietnam, Ho Xuan Huong's Poetry, Sense of Femininity, Gender Equality, Autonomy

\section{Introduction}

In the medieval Vietnamese literature from the $18^{\text {th }}$ century to the end of the $19^{\text {th }}$ century, Ho Xuan Huong was one of the young female poets who refused to depend on the male-dominated world, and who was at the same time talented with an enriching soul. Not only was she the most talented female poet in medieval literature in the late Le and early Nguyen Dynasty period, she was also the most typical Vietnamese medieval author in terms of sense of femininity. Such a ta- 
lented female poet she was, with many excellent works of Nom poetry, Xuan Huong's life still could not escape loneliness ${ }^{1}$. Ho Xuan Huong has created many poems showing the attitude of resistance to feudalism, regaining the rights of women and expressing a strong sense of femininity. Ho Xuan Huong's poetry is a song about the beauty of the soul, talent and body of a woman; is a strong voice defending women, fighting for women's freedom, equality and happiness. Ho Xuan Huong is a great poet of Vietnam, loved and admired by many Vietnamese people. Moreover, she is the earliest and strongest humanist poet and feminist in Vietnam. Her works have been translated into many languages and are widely known around the world. Through 76 poems including Luu Huong $K y$ and the known legends ${ }^{2}$ [1], her sense of femininity can be clearly felt.

\section{The Connotation of Sense of Femininity}

Relevant to the concept of femininity in Chinese literature, Song Geng has the literary work called The Fragile Scholar. Power and Masculinity in Chinese Culture (2004) [2], Ventriloquized Voice: Feminist Theory and English Renaissance Texts by Elizabeth D. Harvey (1995) [3]. Regarding the image of women, the literary works that helped us form the idea are Expression of self in Chinese literature by Richard C. Hessney, Robert E. Hegel (1985) [4], Abandoned women and poetry by Lawrence Lipking (1988) [5], Gendered Persona and Poetic Voice: The Abandoned Woman in Early Chinese Song Lyrics by Maijia Bell Samei (2004) [6] ... In this article, based on theories of literary criticism from a feminist perspective, for the connotation of sense of femininity, we believe it is necessary to basically clarify two aspects: The first is from a woman's view of herself, affirming her position, understanding her self-worth in the society, and being aware of her right to live a happy life; the second is from a woman's view of the outside world, which also explains the unique features endowed with a woman's life. In the social life of Vietnam in the feudal period, the sense of femininity was something strange but not completely foreign, since it was also a feature of the original culture of the nation.

Sense of femininity, an important part in the field of womenstudies, is not only the core concept of female literary theory but also an important measure of female literary evaluation and criticism. The concept of femininity in Confucian literature is the basis for us to analyze and explain the sense of femininity in Ho Xuan Huong's poetry. The Confucian conception of femininity also has much in common with the universal conception of femininity. Femininity is qualities considered to be characteristic of women. It is a set of natural and social qualities, the ability to reproduce lives and take care of house work. Ho Khanh Van stated: "The word femininity is used both as a noun (femininity, womanhood) and an adjective (feminine). While the word woman is often used to refer to an

${ }^{1}$ Some of her famous works can be mentioned such as: Moi Trau, Tu Tinh, Lay Chong Chung, Ba Doi Pass, To Sam Nghi Dong.

${ }^{2}$ The article uses poetic texts extracted from poetry of Ho Xuan Huong, selected and introduced by Dao Thai Ton, education publishing house, Hanoi, 1997. 
object, a person carrying the feminine gender, the word femininity is used to refer to nature and character, meaning looking into the matter of being. Femininity includes the typical characteristics of women that are revealed in the behavior and relationships that are normative in society and culture" ([7]: p. 30). For the connotation of sense of femininity, it is necessary to basically clarify two aspects: The first is from a woman's view of herself, affirming her position, understanding her self-worth in society, and being aware of her right to live a happy life; the second is from a woman's view of the outside world, which also explains the unique features endowed with a woman's life. In the social life of Vietnam in the feudal period, the sense of femininity was something strange but not completely foreign, because it was also a feature of the original culture of the nation. The sense of femininity in Vietnamese literature is also expressed in the same way, thanks to the female poet's creation, readers can feel their sensitivity from the perspective of women on the uniqueness of the outside world. The literary works by female poets or "female-voiced literature" in the medieval time, which expressed their sense of resistance to feudal rites, attack towards the male-dominated society and fight for equality between men and women, was the natural reveal of sense of femininity ${ }^{3}$.

As commented by La Nham Thin: "Ho Xuan Huong's poetry is a self-conscious voice full of bravery sense of individuality and sense of one's own gender" (La Nham Thin, 2016: 197) [8], literary works by Ho Xuan Huong clearly showed that sense of femininity. Her behaviors awakened the whole world around her, her poems showed the tragic and pitiful situation of the women's world, as well as the unequal relationship between men and women in the society. Le Thu Yen also affirmed: "Xuan Huong's view expressed in her poetry was a reverse view, not against her own thoughts but against the time" (Le Thu Yen, 2008: 64) [9]. By studying the sense of femininity in her poetry, we understand even more about the personality of Ho Xuan Huong, the poetry of Ho Xuan Huong, and also the humanistic spirit of traditional Vietnamese culture.

\section{Ho Xuan Huong's Femininity in the Context of Medieval Vietnam}

\subsection{The Concept of a Family with an Equal Husband-and-Wife Relationship in Ho Xuan Huong's Poetry}

According to Simone De Beauvoir: "Sense of femininity is women's self-consciousness of her own worth and status as a subject that exists equally alongside men" [10]. Ho Xuan Huong's sense of femininity is reflected in the search for equality between men and women in love and marriage. Ho Xuan Huong's love and marriage life was bleak and difficult. She was twice married asa concubine, but even more unfortunate, she sufferedfrom the death of her

${ }^{3}$ There are five works that prominently show Ho Xuan Huong's feminist voice, namely Banh Troi Nuoc, Khong Chong Ma Chua, Thuong Thay Phan Gai, Lay Chong Chung, Tu Tinh. 
husbands twice. This allowed Ho Xuan Huong to understand the feelings of women in the same situation. In her poetry, there are $42 / 76$ poems (accounting for 55.3\%) that reflect the images of women with their tragic identity and low status in the feudal society. Among those, the poem "On sharing a husband" clearly expressed that bitter feeling and at the same time condemned the injustices against women: "Screw the fate that makes you share a man/One cuddles under cotton blankets; the other's cold/Every now and then, well, maybe or maybe not/Once or twice a month, oh, it's like nothing/You try to stick to it like a fly on rice/But the rice is rotten/You slave like the maid, but without pay/If I had known how it would go/I think I would have lived alone" (On sharing a husband). Here, the poet described the status of women as concubines, which was also the real situation of thousands of thousands of women in feudal society. According to Ho Xuan Huong, putting women in the situation of being concubines is a bad and unfair treatment for them. Featuring in her poetry the suffering and hatred of many women through hundreds of years of feudalism, Ho Xuan Huong expressed the curse of polygamy; fiercely challenged the unreasonable feudal marriage regime; pursued equality between men and women; expected and demanded monogamy. All of the above clearly shows the sense of femininity in her poetry.

\subsection{The Female Poet's Sense of Autonomy in Communication and Composition}

Not only a talented female poet, Ho Xuan Huong also has an enormous heart towards life, an aspiration not only for herself but for all the women of her time, which is the desire to liberate women. Marx wrote: "In its reality, human nature is the synthesis (the sum) of social relations" [[11], p. 191]. Then there is no reason why one gender should be free, while the other is limited and cut off from all relationships other than those within the family. She encouraged women to reach for freedom, first of all in love. As a female poet, Ho Xuan Huong also aspired to step out of the zenana, freely socialize and compose poems together with many other poets. 26 out of 76 poems (accounting for 34.2\%) on this topic was an opportunity for her to show her sense of autonomy in communication and composition. Let's take this poem for example: "How faithful we are to each other/Words of love in just a few steps of farewell/A silent evening without swallows/Time just flees by/Tears on flowers are our old way/Scent in the mattress all night long/Absence helps us realize our love/How faithful we are to each other" (Hoa Son Phu chi tac, the poem in response to that of Mai Son Phu). The poem above was not written by a female poet of the $20^{\text {th }}$ and $21^{\text {st }}$ centuries, but by Ho Xuan Huong at the end of the $18^{\text {th }}$ century for her lover, Mai Son Phu. This love poem featured the composition scene of Ho Xuan Huong and her lover. According to Thach Quy: "This is a poem marking the first love, the love from a young age, innocent and pure but also very passionate and sincere, between Ho Xuan Huong and a young man called Mai Son Phu. Mai Son Phu at 
the time was just a student who hasn't yet completed his studies or achieved any titles, but Ho Xuan Huong fell in love with him with a 'lightning love', meaning an overwhelming love at first sight" [12]. The poem showed the sense of liberation in the thought of a feudal woman. In communication and composition, the female poet gradually entered the male-dominated world, conducted a dialogue with them using the right attitude, thereby raising the position of women. By writing everything she wished to express, affirming her talent and passion for literary creation, Ho Xuan Huong also affirmed her sense of femininity.

\subsection{The Woman Wants and Plays the Role of a Gentleman}

According to the traditional Confucian concept: A husband's role is to take care of external affairs. The role of being a wife at home is to carefully submit to the husband, help him teach the children, take care of the house, preserve property and maintain family etiquette. Therefore, as the second class, in the feudal society, the zenana and kitchen are small pieces of land of women's life. Those principles masked a woman's freedom in the form of beliefs imposed from birth. Ho Xuan Huong did not think so, the female poet was earnest and longing to reach the outside world. She also condemned the notion that women are anonymous, the most inferior, the "despicable", the kind of people that are difficult to educate. Xuan Huong seemed to want to state that, not only in love, a woman also shows her proactiveness, decisiveness and bravery in many other fields. And in eloquent words, her poetry described the beauty of women so that the male-dominated world would recognize and respect them.

The woman Ho Xuan Huong, as a dependent product of the male-dominated society, refused to appear weak compared to masculinity though. In her poetry, there are 8 out of 76 poems (accounting for 10.5\%) showing her interest in the contemporary political state. The poem titled "De den Sam Nghi Dong, written at the Sam Nghi Dong temple" was an outstanding example: "Looked around and saw the hanging board/ There it is the temple of the district head standing precariouslyl If I could change my fate to become a gentleman/How heroic that would be" (De den Sam Nghi Dong). The poem proves that Ho Xuan Huong refused to be on the fringes of the feudal male-dominated society and expressed her desire to be equal to men in all social fields. The poem shows Ho Xuan Huong's desire to be equal and establish a glorious and heroic career like men. That was her challenge and duel to the male-dominated world. Since she cared a lot about the relationship between women and "the gentlemen", in her poetry the "sages" were a world of images parodied, flipped, brought down and degraded.

Ho Xuan Huong's era and ours are very far apart, yet there are interesting similarities in the sense of femininity in her poetry in terms of love and marriage, socializing and playing the role of gentlemen. Xuan Huong's poetry shows the awakening and maturity of the sense of femininity in the extremely difficult situation of the feudal society. Of course, the sense of femininity expressed in her 
poetry also has many unique points.

\section{Distinctive Features of the Sense of Femininity in Ho Xuan Huong's Poetry}

Under the oppression of the contemporary feudal rites and her difficult personal circumstances, the sense of femininity in Ho Xuan Huong's poetry also has distinct features. In medieval Vietnamese poetry, Ho Xuan Huong was the female artist with the most poems expressing contempt for feudal rites and challenges to the male-dominated society. The artistic image in her poetry originated from the reality of life, in which women were deservedly promoted. And by laughing in their face just as storms, the masks impersonating gentlemen and heroes were torn, exposed and stripped naked so that the hypocritical robes revealed the lowliness, vulgarity, and infamy of the world, which was worthy of condemnation in the feudal society of old age (a few poems such as The Folding Fan, Blaming an Ignorant Student, Quan Su Pagoda, Cobra Monk, ...). She not only lamented suffering for herself, but also spoke out for women in the whole society. Her sense of femininity transcended her "ego" to reach the whole society. Let's take her poem "Girl without a sex" for example: "Did the fairy midwives have a falling outl And somehow misplace her maidenhead?/The little father mouse squeaking about, doesn't care/Nor the mother honeybee buzzing along, fat with pollen/Can anyone tell whether it's ovule or anther?/Can anyone say if it's stem or bud?/ Well, fine. It's really okay. Since her whole life/ She'll never have to hear "daughter-in-law!" This poem showed displeasure at the cold gaze of the outside world towards a woman who was in the "shackles" of feudal Confucianism but incapable of procreation. They had to endure harsh words like the sound of "a honeybee", of evil people "mouse squeaking". Through that humorous and witty tone, she seemed to give advice to women in that situation, hoping they would not pay too much attention to the sarcastic and humiliating words of the world. Not being able to fulfill the motherhood (being a wife) does not mean being one level inferior to others, nor does it mean they do not have the right to desire romantic love and happiness. Through her deep concern and sympathy for those unfortunates, she expressed her displeasure and condemned the feudal etiquette that binds people.

The sense of femininity in her poetry is close to natural people, very colloquial and folk. It is a natural world full of spring spirits and symbolic of women. Ho Xuan Huong is considered a person with a heart attached to the nation's customs and traditions, who is interested in the daily life of the people. According to our statistics, there are up to $53 / 76$ poems (accounting for $70 \%$ ) by Ho Xuan Huong in which folk language and poetic images of colloquial and everyday life were skillfully applied. Maybe that's why in her world of Nom Duong Luat poetry, the prism of a fertile life is core and the fate of a woman is the biggest concern, a prominent topic (some of the most popular poems include: Jackfruit, Young lady, On a portrait of two beauties, The folding fan, The well, ...). Her 
many poems bearing the sounds and colors of Vietnamese folklore helped people understand and appreciate the talent and personal qualities of the female poet even more. Poet Xuan Dieu once commented: "Ho Xuan Huong is a poet of Vietnamese origin, an exemplary model of the nationalization of poetry, admired by everyone" ([13], p. 338). The woman in Xuan Huong's poetry is very ordinary, petty, simple and weak. They are like a floating cake, "a snail wandering in marsh weeds that smell foul”, a jackfruit, ... but always overflowing with a strong and righteous desire to live. It can be said that, in addition to folklore, Xuan Huong is the first poet in the history of national literature who has given poetry the voice of an ordinary woman.

Ho Xuan Huong's poetry expresses a particularly intense sense of femininityand carries a personal nuance. She shows an attitude of supporting and pursuingthe sense of femininity, aspiring to lead an independent life in love and a happy marriage, to be free to socialize, to compose, to stand alongside with the gentlemen,... Phan Hong Hanh stated: "Ho Xuan Huong's poetry shows resistance to being voiceless, resistance to an obscure way of life, and resistance to two oppressions at the same time, namely, power and men" ([14], p. 9). Not only is the voice of sympathy, compassion and strong protest for the pitiful and small lives of the "second class" in the society, her poetry also expands the scope of content reflecting on the world of women.

The sense of femininity expressed in the literary works of the female poet Ho shows sensitivity from a female perspective when perceiving the uniqueness of the outside world. The literary works of the female poets or "female-voiced literature" in the medieval age, which expressed their sense of resistance to feudal rites, attack towards the male-dominated society and fight for equality between men and women, was a natural expression of sense of femininity. In the early $18^{\text {th }}$-late $19^{\text {th }}$ century, Ho Xuan Huong's poetry took the femininity element in literature to the next level. In particular, that poetry affirmed a truth that women today still pursue: Women must and need to be free to take charge of their destiny. Bringing with them the desire for happiness and mastery of life, the women in Xuan Huong's poetry are really the owners of the discourse on feminism in the contemporary Vietnamese Confucian society. Accordingly, the spirit of upholding women is indeed an aspect of the renaissance of the nation's indigenous culture, in which the value of women is highly regarded and honored. By studying thesense of femininity in her poetry, we understand more about the personality of Ho Xuan Huong, her poetry, and also the humanistic spirit of traditional Vietnamese culture.

\section{Conclusion}

Along with the female poets in Vietnam during the feudal period in the 18th-19th centuries, Ho Xuan Huong "deserves more than anyone else to be a woman's poet" (Nguyen Loc, 1983: 20) [15]. Ho Xuan Huong's poetry expresses a particularly intense sense of femininity and carries a personal nuance, as well 
as "a universal woman, a universal person" (the word used by Doan Le Giang) with the enlightenment of modern colorful, feminine consciousness. The sense of femininity flows through the beauty of the soul and intellect, somewhat softening the tragedies of Ho Xuan Huong's life. Each woman has an expression of feminine consciousness. The feminine consciousness in Ho Xuan Huong's poetry has the appearance of her life and identity. The article is only limited to studying Ho Xuan Huong's poetry from the perspective of feminine consciousness, while other issues of feminist critics have not been mentioned, such as gender discourse, the issue of fighting for women's rights.

\section{Conflicts of Interest}

The author declares no conflicts of interest.

\section{References}

[1] Dao, T.T. (1997) Poetry of Ho Xuan Huong (Selection). Education Publishing House, Hanoi.

[2] Song, G. (2004) The Fragile Scholar: Power and Masculinity in Chinese Culture. Hong Kong University Press, Hong Kong (China).

[3] Harvey, E.D. (1992) Ventriloquized Voice-Feminist Theory and English Renaissance Texts. Routledge, London, New York. https://doi.org/10.4324/9780203359419

[4] Hessney, R.C. and Hegel, R.E. (1985) Expression of Self in Chinese Literature. Columbia University Press, New York.

[5] Lipking, L. (1988) Abandoned Women and Poetry. University of Chicago Press, Chicago.

[6] Samei, M.B. (2004) Gendered Persona and Poetic Voice (The Abandoned Woman in Chinese Song Lyrics). Lexington Books, Maryland.

[7] Van, H.K. (2020) Critique of Vietnamese and Chinese Feminism and Female Prose (Cases of Da Ngan and Thiet Ngung). Thesis of Doctorate in Literature, Ho Chi Minh City University of Social Sciences and Humanities, Ho Chi Minh City.

[8] Thin, L.H. and Thanh, V. (Co-Editors, 2016) Textbook of Vietnamese Medieval Literature. Volume 2. Education Publishing House, Hanoi.

[9] Yen, L.T. (2008) The Attractiveness of Ho Xuan Huong's Nom Poetry. Literature Publishing House, Hanoi.

[10] De Beauvoir, S. (1996) The Second Sex (Translated by Nguyen Trong Dinh, Doan Trong Thanh). Vol. 1, Women's Publishing House, Hanoi.

[11] Marx, K. (1995) Friedrich Engels. Full Set, Vol. 3, National Political Publishing House, Hanoi.

[12] Quy, T. (2018) The Issue on Ho Xuan Huong-Trying to Approach Poems of Textual Origin.

http://khxhnvnghean.gov.vn/?x=1162/nghien-cuu-khxhnv/van-de-ho-xuan-huongthu-tiep-can-nhung-bai-tho-co-goc-nguon-van-ban

[13] Dieu, X. (1987) Vietnamese Classical Poets. Literature Publishing House, Hanoi.

[14] Hanh, P.H. (2008) Feminine Divinity in the Poems of Modern Vietnamese Female Poets. Thesis of Master in Linguistics, Hanoi University of Social Sciences and $\mathrm{Hu}$ manities, Hanoi.

[15] Nguyen Loc. (1983) Poetry of Ho Xuan Huong. Literature Publishing House, Hanoi. 